\title{
A integração do Brasil no Império Colonial Português
}

\author{
JOÃO MARINHO DOS SANTOS \\ Universidade de Coimbra
}

1. A descoberta, por uma armada portuguesa sob o comando de Pedro Álvares Cabral, a 22 de Abril de 1500, da «Terra de Vera Cruz», a que o vulgo passou a chamar Brasil, constitui, hoje, um facto histórico de veracidade apodíctica ou categórica. Não porque não se tenham perfilado outros protagonistas de um eventual acto descobridor anterior ao de 1500. Só para dar um exemplo: em 1922, Jaime Cortesão aceitava que Duarte Pacheco Pereira, o autor do Esmeraldo de situ orbis, realizara, ao serviço de D. Manuel I, uma viagem à América e que tal viagem fora «de descobrimento ou talvez mais propriamente de reconhecimento ao mesmo Brasil» (cf. A expedição de Pedro Alvares Cabral e o Descobrimento do Brazil, Lisboa, Livrarias Aillaud e Bertrand, 1922, pp. 155-156). Com efeito, o carácter apodíctico de tal facto advém-lhe do próprio significado do conceito «descobrir». Explicitemos. 
Em 1922, Jaime Cortesão mostrava-se quase escandalizado por o historiador americano Vignaud estar convicto de que Cabral não fora o primeiro descobridor do Brasil, mas que tal certeza não tinha importância nenhuma. E citava-o: «une découverte n'est effective, que lorsqu'elle a une suite. Qu'importe que Pacheco et d'autres aient vu le Bresil les premiers, si personne ne l'a su, si on n'a pas pris acte? [...] La découverte en pareil cas, est comme si elle n'avait pas eu lieu; celle de Cabral étant la seule qui ait été constatée par des documents authentiques, la seule dont le Portugal ait repris acte et qu'il ait notifiée au monde, est la seule qui compte» (apud Jaime Cortesão, Ibidem, pp. 158-159).

Rememoremos que, na verdade, as cartas de Pero Vaz de Caminha e de mestre João, físico, escritas do Brasil e a relação de toda a viagem feita por um piloto anónimo da armada de Cabral, bem como a carta de D. Manuel para os Reis Católicos, escrita poucos dias depois da chegada de Cabral, testemunham, à saciedade, que Portugal assumiu, então, a descoberta em causa e que a divulgou ao mundo. Isto para não falar já da correspondência de alguns italianos residentes em Lisboa, pela qual foi também divulgado o referido acontecimento.

Sugestionado ou não por Vignaud, Vitorino Magalhães Godinho, admitindo embora que «descobrir» e «descobrimento» não têm o mesmo significado em relação a todos os tipos de espaços descobertos em Quatrocentos e Quinhentos, enunciará como elementos-chave dos referidos conceitos, se bem interpretamos: a consciência de se ter descoberto/achado algo de que nada se sabia do que se vai encontrar (ainda que se saiba do que se vai em busca); a surpresa, sob a forma de novidade, e a sua pública notificação; o contacto ou a comunicação entre o espaço descoberto e o espaço de largada, através de tecnologia adequada e que erradique, portanto, o mero acaso (A Ideia de Descobrimento e os Descobrimentos e Expansão, in "Anais do Clube Militar Naval», vol. CXX, Out.-Dez. 1990, pp. 627-642). 
No caso da descoberta do Brasil, por Pedro Álvares Cabral, é manifesto: que ela trouxe novidades a círculos culturais que, pelo menos aparentemente, não dispunham desses conhecimentos; que houve já alguma apreensão do espaço e que a comunicação entre o Reino e a nova descoberta passou a estar alicerçada em sólida tecnologia, o que permitiu, logo no ano seguinte, mais propriamente a 10 de Maio de 1501, enviar-se nova armada de três embarcações para prosseguir o descobrimento da «Terra de Vera Cruz»; que houve divulgação da descoberta de Cabral; que houve algum interesse por este novo objecto das descobertas, em termos oficiais. Será desta última particularidade que, de imediato, nos ocuparemos.

2. É sabido que qualquer espaço é, antes do mais, um meio de vida, servindo portanto, directa e indirectamente, de suporte a um maior ou menor número de usos, ou seja, é a actividade económica e social dos homens que, sobretudo, transforma o espaço em recurso. Então, pergunta-se: que usos poderia proporcionar ao rei e ao reino de Portugal, bem como à «Respublica Christiana»/Cristandade, a Terra de Vera Cruz?

O primeiro valor de uso que, potencialmente, motivou os descobridores foi o ouro: «Falava [um velho índio], enquanto o Capitão esteve com ele, perante nós todos, sem nunca ninguem o entender, nem ele a nós quantas cousas lhe demandávamos acerca d'ouro, que nós desejávamos saber se na terra havia» (Carta de Pero Vaz de Caminha). Mas, o próprio Caminha, traduzindo, por certo, o pensamento dos companheiros, avançará logo com outros usos potenciais de uma terra tamanha, com «bem vinte ou vinte e cinco léguas por costa», montanhosa em parte, muito cheia de grandes arvoredos, de bons ares, «assim frios e temperados, como os de Entre Doiro e Minho», com muita água, pelo que, «querendo-a aproveitar, dar-se-á nela tudo».

Assim, se bem interpretamos, ao pretenso uso industrial (o da extracção do ouro), os primeiros descobridores acrescentaram outros, 
como o da «Terra de Vera Cruz» estar em condições de ter aptidões agrícolas (entenda-se agro-pecuárias) e até o de ser adequada ao habitat dos portugueses, se não mesmo poder servir o lazer. Mais: constituía já um uso real o da sua posição geo-estratégica, antevendo-se, portanto, que o novo espaço seria como que uma «pousada para esta navegação de Calecute», ou seja, para a rota do Cabo. Com efeito, como é sabido, pelos condicionalismos naturais, houve a necessidade de distender muito, à ida, a rota no sentido da América Meridional, a ponto de se exigir aos pilotos que tivessem cuidado para as embarcações não arribarem.

Não se fica por aqui o levantamento dos usos múltiplos, potenciais e reais, da «Terra de Vera Cruz», feito pelos descobridores oficiais. Caminha dará, igualmente, conta de um outro, embora de natureza espiritual: o uso ou o «fruto que dela se pode tirar me parece que será salvar esta gente», aliás «gente boa e de boa simplicidade». Recorde-se que, sob uma prática comum aos diversos actos das descobertas, Cabral procederá, de imediato, à sacralização do novo espaço, mandando implantar, solenemente, na praia, a cerca de 300 metros a oes-noroeste da foz do Mutari, uma cruz de madeira, com as armas e a divisa do rei de Portugal (cf. Carta de Pero Vaz de Caminha e Jaime Cortesão, Cabral $e$ as origens do Brasil, Rio de Janeiro, Edição do Ministério das Relações Exteriores, 1944).

É também sabido que a armada de Pedro Álvares Cabral integrava missionários franciscanos, mas não consta que algum tivesse ficado na nova Terra. O seu destino era o Oriente. Enfim, a integração do Brasil na «Respublica Christiana» só haveria de encetar-se cerca de meio século após a descoberta, ou seja, quando, em 1549, chegarem à Baía, na comitiva do governador Tomé de Sousa, o P Manuel da Nóbrega e mais três padres da Companhia de Jesus, além de dois irmãos leigos. Dedicaram-se, predominantemente, à catequização dos índios, já que as preocupações espirituais com os europeus recaíram sobre um clérigo 
secular vindo do Reino para S. Salvador da Baía. Deste modo, a menos de um ano da sua chegada, partirão para o sertão de S. Vicente, a 240 léguas de distância da Baía, o P Leonardo Nunes e o irmão Diogo Jácome e, em 1553, chegará o segundo grande apóstolo do Brasil, o espanhol e ainda então leigo, José Anchieta, o qual morreu provincial da Companhia após 40 anos de apostolado.

$\mathrm{E}$, nesta maré de evocações, difícil é esquecer o $\mathrm{P}^{c}$ António Vieira, mas não esqueçamos, igualmente, a plêiade de missionários Franciscanos, Carmelitas, Beneditinos e Mercedários que ajudaram a construir o Brasil. Evoquemos o seu esforço na defesa da escravização dos índios, mas tenhamos também presente que, sem o recurso à escravatura, não se teria verificado, então, a colonização do Brasil. Façamos, enfim, suficiente justiça à hierarquia eclesiástica, pretensamente acusada de pactuar com a cobiça desenfreada dos traficantes negreiros. É que, muito antes de Vieira fazer ouvir a sua voz, já, em 1563, por uns Apontamentos depois das Cortes de 1562 do Senhor D. Sebastião em Lisboa (B.N.L., cód. 2692), os prelados portugueses lembrarão as particulares «vexações, que na Mina affirmão que se fazem aos convertidos á fé, de que vem serem ate agora tão poucos, e quantos nella, e em todos aquelles Rios de Guiné cativão contra toda a justiça, e razão, e contra toda humanidade. VA. deve mandar ver bem isto, e tomar informação, que per muitos, que aqui estão nesta cidade [Lisboa] pode aver, e saber a certeza disso per testemunhas como cumpre acodir a tão grande roubo, e deserviço de N. Senhor». Não nos dispersemos, porém.

Além dos elementos materiais e imateriais que a «Terra de Vera Cruz» poderia oferecer (o que a convertia em recurso) e da multiplicidade dos seus usos potenciais e reais (o que lhe conferia uma considerável importância), retenha-se, igualmente, a noção relacional entre o novo recurso e o sujeito-titular. Com efeito, o descobrimento do Brasil 
processou-se em nome do rei de Portugal, com gente e navios seus, sob o comando de um capitão-mor e com poderes delegados pelo dito rei: «[...] lhe damos todo nosso inteiro poder e alçada da quall em todollos cassos ataa morte naturall ussaraa inteiramente e se daram a emxucaçam seus juizos e mamdados ssem delle aver apelaçam nem agravo» (carta régia, de 15 de Fevereiro de 1500, in Frei Gonçalo Velho por Ayres de Sá, vol. I, Lisboa, Imprensa Nacional, 1899, doc. CLXV, pp. 283-285).

Portanto, é em nome do rei de Portugal que Cabral se apodera da nova terra descoberta, sem recorrer a qualquer conquista ou acção armada, e dela obtendo já, como se disse, parcial conhecimento. Além disso, diligenciará por saber mais, pelo que serão logo lançados ali, em Porto Seguro, dois degredados, sem esquecer que mandará também, de imediato, pelo navio dos mantimentos, nova do achamento da terra, com vista a «melhor a enviar descobrir e saber dela mais do que nós agora podíamos saber, por irmos de nossa viagem». Mais: prescindiram os descobridores de enviar ao rei mostra do património genético de uma espécie humana logo considerada pura, por ninguém, no Reino, vir a entender os eventuais índios seleccionados e para não fazer, internamente, escândalo; mas, não prescindiram de enviar ao titular da nova terra mostras do património cultural da respectiva etnia/nação: uma pedra verde que um velho trazia no beiço furado, barretes de penas de aves e outras coisas.

Aliás, a aculturação iniciou-se logo, com os portugueses, por exemplo, a dançarem ao som de uma gaita de foles tocada por um gaiteiro português e de um «tamboril dos nossos», e com alguns dos «deles»a tangerem corno ou buzina e a saltarem e a dançarem à sua maneira.

Voltando, porém, à questão da titularidade, retenha-se que o rei de Portugal era um titular delegado e um gestor do novo recurso, já que, em última instância, essa titularidade pertencia ao Papa, como representante de Deus na terra. A Ele, ao Deus dos cristãos, pertencia, 
de facto, todo o Orbe, sendo os homens que $\mathrm{O}$ reconheciam seus usufrutuários, pelo que, no mínimo, deveriam pagar à Igreja de Roma ou aos seus representantes o dízimo dos frutos.

Não vamos rememorar, aqui e agora, o conjunto de bulas e breves papais que, reconhecendo o papel missionário de Portugal e a legitimidade de fazer guerrajusta aos infiéis muçulmanos e aos gentios inconversíveis, conferiu aos monarcas lusos a posse temporal e espiritual das terras conquistadas e descobertas. Quereríamos, porém, explicitar que, tanto numa perspectiva mais económica, como noutra de natureza mais sócio-política, se nos afigura que a Carta de Pero Vaz de Caminha procura transmitir da «Terra de Vera Cruz» uma imagem forte de que ela poderia constituir um património, quer pelo objecto em si (ou seja, pelos múltiplos usos, potenciais e reais, do território), quer pela noção relacional que o(s) titular(es) (a Cristandade e o rei de Portugal) poderiam estabelecer com esse mesmo objecto, quer pela reserva de valores (variáveis ao longo dos tempos) que poderiam concorrer para a salvaguarda da identidade e da autonomia dos respectivos titulares.

Convicto, talvez, de que tinha ali um importante património, foi assim que D. Manuel deu, de imediato, continuação à descoberta do novo espaço e inaugurou um ciclo de usos económicos centrado na extracção do pau-brasil. Por sua vez, sobretudo o seu sucessor, D. João III, procederá à defesa desse património, quando ele passar a ser cobiçado por estranhos à nação portuguesa, ou seja, quando se perfilarem outros candidatos a titulares, designadamente os franceses luteranos, logo concorrentes e inimigos da «Cristandade».

Parece-nos, pois, não haver dúvida de que o descobrimento do Brasil suscitou, de imediato, na Coroa/Estado de Portugal, como seu titular delegado e gestor, um interesse suficiente que levou não só a tentativas Para apreender o espaço disponível dentro dos limites do Tratado de Tordesilhas (veja-se a tradução desse esforço ao nível da cartografia, 
inclusive com a elaboração do mapa dito de Cantino, logo em 1502), mas também ao começo da satisfação do proveito económico. Estes dois vectores concorreram, portanto, para dinamizar, a curto prazo, a integração do Brasil no Império Colonial Português.

Mas, outra questão será a de sabermos quais os limites dessa integração, ou qual o peso relativo do Brasil no conjunto do Império Português Quinhentista.

3. Não há qualquer espécie de dúvida de que o descobrimento do Brasil não suscitou resultados idênticos aos de um outro acontecimento quase sincrónico - a chegada dos portugueses à Índia, em 1498. Poderemos aferir tais resultados pelos valores centrais para a época, mais propriamente, em termos de honra, proveito, fama e glória.

Em primeiro lugar, assinale-se que o feito de Vasco da Gama distendeu, consideravelmente, a territorialidade (incluindo, obviamente, a hidrosfera) do Império Português e, consequentemente, da «República Cristã». D. Manuel, seguindo aliás um critério estabelecido por D. João II (com quem rivalizará em prestígio e glória), medirá esse alargamento em léguas lineares, tendo os seus cosmógrafos apurado que, ao ligar Lisboa a Calecute, Vasco da Gama descobriu quase tantas léguas (1550) como as que haviam sido dadas a conhecer aos ocidentais desde o início da Expansão Portuguesa (1885 léguas). A esta característica associar-se-á, quanto ao feito do Gama, uma outra que o valorizava: a circunstância de se tratar de um espaço muito distante (a «última das terras», no dizer de Diogo do Couto).

Ora, se ao nível da fama e da glória estes valores se geravam, na época, em função dos perigos vividos e, particularmente, em função das distâncias a que as descobertas e conquistas eram realizadas, é óbvio que o descobrimento do Brasil, processando-se no decorrer de uma viagem para a Ásia, não suscitou para o enviado do rei e para o 
próprio rei mandatário tanta fama e tanta glória, como a descoberta do Gama.

Depois, os valores de uso e de troca proporcionados, real e imediatamente, pelos territórios cotejados - a Índia e o Brasil - estarão longe de serem considerados equivalentes em termos de proveito. $\mathrm{O}$ da Índia será publicitado, no essencial e sem qualquer hesitação, por um degredado da frota do Gama, quando lhe perguntaram dois mouros de Tunes que encontrou em Calecute: «[...] que vinhamos buscar tam lonje e elle lhe respondeo vimos buscar christãos e espeçiaria» (Diário, atribuído a Alvaro Velho, p. 36). Assim, se com o êxito da expedição do Gama aqueles e outros apreciados valores orientais passaram a estar praticamente à disposição do rei e do reino de Portugal, bem como da República Cristã, manifestamente, no caso do Brasil, com a expedição de Cabral, só se depara um potencial campo de cristãos e não se topa nem com o fúlgio ouro, nem com a rica especiaria. Deste modo, se compreende que D. Manuel passe, orgulhosamente, a intitular-se «per graça de Deus rey de Purtugal e dos Alguarves daquem e dalem maar em Africa senhor de Guinée e da conquista navegaçom e comercio de Ethiopia Arabya Persia e da índia», e não do Brasil, relevando, em vária documentação, particular apreço por senhorear a «Índia», um espaço almejado por qualquer imperador da época. Consequentemente, exultará, por várias vezes, com os serviços prestados pelo Gama, particularmente «no descubrymento das Índias, e asento delias o qual não somente redundou e redunda em grande proveito nosso e do de nossos reynos e senhoryos mas gerallmente em proveyto unyversall dos moradores delles e de toda a crystandade» (cf. carta régia, de 17 de Dezembro de 1519).

Deste modo, embora com acidentes de percurso (porque o poder absoluto de D. Manuel não consentia, a quem quer que fosse, situações de excepção), Vasco da Gama acabará por se posicionar, facilmente, na área central do poder, através de galardões vários, como a atribuição do 
título de «dom» $\operatorname{logo}$ em 1500, a concessão do cargo de «almirante da Índia» no mesmo ano, a atribuição da dignidade de conde em 1519 e a nomeação como «vice-rei da Índia» em 1524, ano em que morrerá em Cochim a 25 de Dezembro.

No que concerne aos elevados proventos económico-financeiros que D. Manuel concede ao Gama (porque também ele os proporcionara ao rei, ao Reino e à Cristandade), recordaremos:

O proveito material de Vasco da Gama, com a sua viagem inaugural à Índia, concretizou-se, de imediato, na obtenção de um rendimento anual de 300\$000rs, com carácter hereditário. Igualmente apreciada pelo Gama e pela família, foi a permisssão de poderem investir, uma vez em cada ano (mas com carácter hereditário também), 200 cruzados ou 80\$000rs na aquisição de quaisquer mercadorias provenientes da Índia, sem pagamento de direitos, excepto a satisfação da vintena que reverteria para a Ordem de Cristo. Tratou-se de um benefício de alto valor económico, já que, segundo João de Barros, no terceiro decénio de Quinhentos, estes 80\$000rs poderiam gerar, com o seu emprego em especiaria, cerca de $2720 \$ 000$ rs, ou seja, poderiam valorizar-se 34 vezes. Sem poder doar a Vasco da Gama as rendas da vila de Sines, o rei mandou pagar-lhe, anualmente, pelos rendimentos da Casa de Mina, 400\$000rs (cf. alvará régio, de 20 de Fevereiro de 1504).

Feito conde, como se disse, a 29 de Dezembro de 1519, a 20 de Janeiro do ano seguinte, pelo seu «assentamento», Vasco da Gama passou a receber $102 \$ 864 \mathrm{rs}$ anuais. Isto além de outras doações proveitosas para o Gama e para a família.

Cotejemos, agora, estes benefícios com os que, tanto quanto sabemos, Pedro Álvares Cabral recebeu das mãos de D. Manuel, pela sua viagem à Índia em 1500-1501, incluindo a descoberta do Brasil.

Os primeiros documentos sobre benefícios económico-financeiros, em favor de Cabral, e de que havemos conhecimento, são duas provisões 
reais, ambas datadas de 4 de Abril de 1502: uma no valor de 13\$000rs e outra no de 30\$000rs e cujo resumo se encontra in Alguns Documentos do Archivo Nacional da Torre do Tombo ácerca das Navegações e Conquistas Portuguezas, Lisboa, Imprensa Nacional, [1892], p. 132. Segue-se um recibo, assinado por Cabral, a 10 de Janeiro de 1515, em que se menciona o pagamento de $200 \$ 000$ rs de tença anual correspondente a 1514 (Apud Jaime Cortesão, A Expedição de Pedro Álvares Cabral e o Descobrimento do Brazil, p. 83). Pelo Livro da Matricula dos moradores da Cassa delRey, sabe-se, ainda, que, no primeiro quartel de 1518, Pedro Alvares Cabral era cavaleiro do seu Conselho e auferia a pensão mensal de $2 \$ 437$ rs, ou seja, cerca de $30 \$ 000$ rs por ano (Ibidem, p. 84). Seriam os tais 30\$000rs que já em 1502 recebia?

Em 1520, a viúva de Cabral, D Isabel de Castro, e os filhos António Cabral e Fernão Álvares Cabral serão contemplados, respectivamente, com a tença de $30 \$ 000$ rs e $20 \$ 000$ rs para cada um, podendo inferir-se que Cabral faleceu por essa altura.

Em resumo: se por estes indicadores não se pode concluir que houve um esquecimento, da parte do rei, dos serviços do descobridor do Brasil, também é manifesto que o descobrimento da India e o descobrimento da «Terra de Vera Cruz» tiveram importâncias muito diferentes, quer nos círculos político-culturais da nação portuguesa, quer nas instâncias europeias. O que se compreende, pelas razões anteriormente aduzidas.

Consequentemente, o feito ou os feitos de Pedro Álvares Cabral, ao contrário dos do Gama, não o alcandoraram à centralidade política, muito embora ele mantivesse a sua elevada fidalguia. A propósito, recordemos que o seu terceiro avô, Álvaro Gil Cabral, foi alcaide-mor do castelo da Guarda, no tempo de D. Fernando e do Mestre de Avis, e que a mulher daquele foi neta de D. Rui Vasques Pereira, tio do Condestável. De Álvaro Gil, nasceu Luis Álvaro Cabral, morgado da casa vinculada do pai, 
escudeiro-fidalgo de D. João I e vedor do Infante D. Henrique. Foi seu herdeiro Fernão Álvares Cabral, casado com D ${ }^{a}$ Teresa de Novais de Andrade (filha de Rui Frei de Andrade, almirante de Portugal), e dos quais nasceu Fernão Cabral, o pai de Pedro Álvares Cabral. Fernão Cabral, fidalgo da casa de D. Afonso V, prestou-lhe assinalados serviços em África e em Castela, tendo exercido, também durante largos anos, o cargo de regedor da justiça das comarcas e correição da Beira e de Riba de Coa. Casou com D ${ }^{a}$ Isabel Gouveia, filha de João de Gouveia, alcaide-mor de Castelo Rodrigo e senhor de Almendra, Valhelhas e Castelo Bom.

Pedro Álvares Cabral nasceu em Belmonte, em 1467 ou 1468, e foi moço-fidalgo na corte de D. João II. Pelo casamento, aliou-se a uma das mais ilustres e poderosas famílias da época, ou seja, a esposa $D^{a}$ Isabel de Castro era terceira neta dos reis D. Fernando de Portugal e de D. Henrique de Castela, filha de D. Fernando de Noronha e D Constança de Castro e sobrinha de Afonso de Albuquerque. Enfim, descortina-se ter uma ascendência mais fidalga que a do Gama e um elevado relacionamento social.

Contudo, como dissemos, Pedro Álvares Cabral não parece ter fruído da centralidade política, apesar da sua fidalguia e dos altos serviços prestados ao rei. Em 1509, Cabral está em Santarém, mais ocupado em alargar as suas propriedades do que envolvido no serviço do rei, ao contrário, portanto, de outros cavaleiros que, pelos seus serviços, acabavam por ser contemplados com apetecíveis mercês e rendas reais. É, pois, neste contexto que se deve interpretar uma carta datada de Calecute, a 2 de Dezembro de 1514, e da autoria de Afonso de Albuquerque, em que confessa a D. Manuel não saber que «descontentamento he este que vosalteza de sua pesoa [dele, Cabral] tem, que asy o temdes lamçado de voso serviço», embora lhe pareça «que a culpa deste feito era sua» [dele, Cabral]. 
Não se sabe ao certo que motivos terão esfriado as relações entre o monarca e o descobridor do Brasil. Houve, porém, quem alvitrasse que, depois de Cabral ter regressado à Pátria, em 1501, D. Manuel decidiu nomeá-lo capitão-mor de outra armada em que se integraria, além de outros, Vicente Sodré. Cabral, ao conhecer a autonomia que o regimento real conferia a Sodré, não aceitou o cargo. Sentiu-se D. Manuel da desfeita? É possível.

Com efeito, não concordamos com Jaime Cortesão quando afirma que «[...] logo desde o comêço do seu reinado o novo monarca [D. Manuel] contrariou a política de D. João II de abatimento da nobreza» (A Expedição de Pedro Alvares Cabral..., pp. 79-80). Em nosso entender, D. Manuel, tentando embora reparar as perseguições e os desfavores de D. João II sobretudo em relação a altos representantes da nobreza de sangue (entre os quais se contou, como se sabe, seu irmão D. Diogo), prosseguiu o trabalho de submeter a nobreza portuguesa à sua vontade real. Dito de outro modo, aproveitando o facto de se manter bem viva na memória da Nação a atitude intransigente de D. João II perante os assomos de um senhorialismo rebelde, D. Manuel, sem repetir os métodos do seu antecessor, não descurou o impulso centralizador. É que, se Portugal pretendia ser, de facto, moderno, não poderia transigir quanto à consolidação do poder real. Por sua vez, perante as exigências da construção do Império Ultramarino, o rei também não podia prescindir do contributo da nobreza, quer fosse nova, quer antiga ou de sangue. Mas, havia limites quanto à aceitação dessa colaboração. O braço-deferro que estabelecerá com Vasco da Gama é disso exemplo. Concretizando: por alvará de 21 de Março de 1507, D. Manuel determinará que o almirante da Índia, membro do seu Conselho e já famoso descobridor da rota do Cabo, retirasse a sua «casa» de Sines (ordenando-lhe mesmo que parasse as obras que ali tinha em curso) e que, um mês depois (no máximo), não entrasse na referida vila ou no 
seu termo sem licença do mestre de S. Tiago e de Avis, de quem a vila era. No caso de ele, Gama (ou de alguém de sua família), prevaricar, pagaria 500 cruzados de pena e sujeitar-se-ia ao castigo imposto «aquelles que nam cumprem os mandados de seu rey e senhor».

E o que é que o rei mandava ou exigia a qualquer súbdito por mais famoso que fosse? Segundo contornos definidos por Afonso de Albuquerque na citada carta em que intervém a favor de Pedro Álvares Cabral, captamos esta imagem do rei: «[...] porque a condiçam dos portugueses he criarnos vosalteza e nos castigar, fazer mercê e nos chamar e desagravar, e se servir de nós, e nos tirar de nosso arrufos e errados comselhos, como jeralmente cada dia vosalteza faz, por omde tornamos logo a pôr nosas vidas [sob] ho cutello como nosso Rey e senhor verdadeiro, e cada hum se trabalha por vos merecer...] (Cartas de Affonso de Albuquerque seguidas de documentos que as elucidam, Tomo I, Lisboa, Typographia da Academia Real das Sciencias, [1884], pp. 353-355).

Acaso Pedro Álvares Cabral corresponderá, com o seu comportamento e a sua conduta, a esta imagem de rei, senhor e pai exigente, a que todos deviam obedecer sempre e que deviam esforçar-se por merecer? Afigura-se-nos que não. Assim, no caso de Pedro Álvares Cabral, apesar dos seus méritos e dos serviços prestados, Albuquerque rogará a D. Manuel: «[...] vos beyjarey as mãaos por ele [Cabral]ser chamado de vosalteza, acomselhado e rreprendido, e tornado em vosa graça e serviço, porque he homem que eu sey certo que tem vosalteza comtemtamento de sua pesoa e de todalas cousas homrradas que nele há, pera allgüuas necesydades de voso serviço que lhe emcarregardes».

Repreendido acabará por ser, igualmente, Vasco da Gama, quando este, no esforço de obter o título de conde, ameaçar abandonar o Reino. D. Manuel, porém, por uma ordem datada de 17 de Agosto de 1518, determinará que o almirante da Índia permaneça até finais do ano em 
curso, recomendando-lhe, ainda, que pense bem e se decida a continuar a servir o seu rei, mas se persistir no propósito de se ir «[...] ainda que nos diso muyto pesará nos vos nam impidiremos vosa ida e levada de vosa molher e filhos e de vossa fazenda movei».

Esta luta entre D. Manuel e D. Vasco da Gama, ao nível da centralidade do Poder, é sobretudo representativa, por nem o descobridor do caminho marítimo para a Índia ter escapado ao poder absoluto de D. Manuel, um poder cujo simbolismo será assim descrito por Damião de Góis: «Assinava elRei tres vezes, e algüa mais na somana em publico, e aho assinar stavam ho scrivam da puridade, e hos -eadores da fazenda [altos oficiais] em geolhos dambalas bamdas da sua cadeira, e hos scrivões da fazenda, e camara em geolhos aho redor da mesa em que assinava» (Chronica do Felicissimo Rei D. Manuel, Parte IV, p. 201).

O que é que permitiu tanto a D. João II, como a D. Manuel, afirmarem, ainda que sob formas diferentes, o seu absolutismo? Fundamentalmente, é nossa convicção, o terem começado a dispor de uma tecnoestrutura mercantil, financeira e militar bastante autónoma, de dimensões apreciáveis e a funcionar com carácter regular. Sumariamente, recordemos que, além do recurso à fortaleza (um equipamento militar susceptível de funcionar com pouca gente e muito dominador em relação aos «outros»), será, sobretudo a artilharia (de estância, encarretada e embarcada), a par dos progressos verificados nas armas pirobalísticas individuais (primeiro a espinguarda, depois o arcabuz e o mosquete), que concorrerá para conferir aos portugueses superioridade tecnológica. Ora, tais progressos permitiam prescindir da nobreza tradicional e tornaram-se mais nítidos a partir do reinado de D. João II, podendo lembrar-se, a propósito, a seguinte informação aduzida por Garcia de Resende: estando D. João II em Setúbal, «com muitos esprimentos que fez achou e ordenou em pequenas caravellas andarem muyto grandes bombardas e tirarem tam rasteiras que hiam tocando na agoa». Por sua 
vez, o símbolo da modernização da tecnologia militar alcançada no seu reinado será «huma nao de mil toneis, a mais forte, e milhor acabada, e a mayor que nunca ate entam fora vista, de tam grossa, forte, e basta liança, e tam grosso tavoado que a artelharia a não podia passar, e tinha tantas bombardas grossas, e outras artelharias, que foy muyto fallado nella em muytas partes» (Crónica de dom João II, pp. 24 e 255). Esta nau quase não navegava; ancorada no Tejo, proclamava porém o poderio político e económico de um rei e de um reino fortemente empenhados nos Descobrimentos e na Expansão ultramarina.

Por sua vez, a organização mercantil e a respectiva tecnoestrutura económico-financeira ultramarina concorrerão, sobremaneira, a partir do momento em que o Príncipe D. João, futuro D. João II, se encarregar dos negócios do Estado (1474), para tornar o poder real menos dependente de uma arrecadação do tipo senhorial. Recordemos, quase ao acaso: que, a apartir de 1472, o açúcar da Madeira vai directamente para a Flandres e o Estado alia-se, como lembrará Vitorino Magalhães Godinho, a poderosos grupos capitalistas; que, pouco depois, é o arranque do comércio dos cereais e do pastel dos Açores; que, quando em 1481 D. João II assumir o trono, chamará a si o monopólio dos produtos principais da feitoria de Arguim, mas que será, entretanto, a Mina que se afirmará como excelente fonte de rendimentos para a Coroa/Estado, pelo menos a partir de $1475 \ldots$

É de crer, pois, que a eliminação do Duque de Bragança em 1483 e do Duque de Viseu no ano seguinte, além da perseguição movida por D.João II a outros representantes da alta nobreza tradicional, esteja relacionada com a autonomia económico-financeira e militar obtida pela realeza.

A partir de D. João II, como se disse, alteram-se os métodos, alargam-se as vias (com destaque para a rota do Cabo) e robustecem-se consideravelmente os réditos da Fazenda real. A propósito, esclareça- 
-se que não era só a iniciativa oficial a afirmar-se; também os particulares (reinóis e estrangeiros) pressionavam a Coroa/Estado a encontrar outros mercados ultramarinos. Por tal, a Nação (entenda-se os grupos influentes ao nível do Poder Central) como que exigirá o comércio das especiarias e drogas orientais e, naturalmente, rejubilará com outra oportunidade comercial - a das tintas do Brasil, enquanto a Coroa/Estado disporá de mais uma fonte de rendimentos, susceptível de robustecer, politicamente, o poder real, um poder (recorde-se) cada vez mais interessado em defender o bem comum e em aplicar leis gerais.

4. Um dos muitos aspectos culturais a que a Carta de Caminha dá relevo é a constatação de que os índios tingiam os seus corpos (sobretudo de tinta vermelha), e que a água (quando eles nela se metiam) «não comia a tintura nem a desfazia, antes quando saía[m] da água, parecia mais vermelha». Terá sido esta observação que levou, quase de imediato, os actores particulares e a instituição gestora da «Terra de Vera Cruz» a explorarem e a exportarem as tintas, particularmente o pau brasil?

O trabalho do corte e do transporte do brasil até às embarcações estava perfeitamente ao alcance dos índios. Já na Carta de Caminha se refere que os aborígenes ajudaram os descobridores «a acarretar lenha e a meter nos bateis» e que cortavam a madeira «com pedras feitas como cunhas, metidas em um pau entre duas talas, mui bem atadas».

Ora, a darmos crédito a Damião de Góis, no ano de 1503, D. Manuel I «mandou Gõçalo Coelho com seis naos a terra de Sancta Cruz, cõ que partio do porto de Lisboa ahos dez dias do mes de Iunho, das quaes por ainda terem pouca noticia da terra, perdeo quatro, e has outras duas trouxe aho Regno, com mercadorias da terra, que entam nam eram outras, que pao vermelho, a que chamão Brasil, bogios e papagaios» 
(Crónica do Felicissimo Rei D. Manuel, Parte I, Cap. LXV, p. 145).

Em começos do segundo quartel de Quinhentos, o pau brasil tem cotação nas praças de Flandres, mas está longe de atingir o valor de outras drogas e especiarias. Para mais, os espanhóis passaram a trazer da América Central grandes quantidades de brasil, o qual concorria com o da «Terra de Vera Cruz». Ora, a esta concorrência feita por outro espaço com o mesmo uso económico, ou com um recurso comum, veio juntar-se a realizada por outros actores estrangeiros (sobretudo piratas e corsários franceses) que, deste modo, ameaçavam a gestão monopolista do rei de Portugal no que concerne à comercialização do pau brasil. É, aliás, D. João III quem, para uso das nossas diplomacia e política externa, determina que se argumente que o que confere algum valor de troca a este produto tintorial é precisamente a prática do estanco ou do monopólio a favor da Coroa de Portugal: «[...] e do Brazil outro tanto, que em toda aquella costa tenho defezo a meus vassalos, que não traga[m] nem hum pao sem minha licença de que me pagão direitos aquelles a que [a] a dou para o trazerem; e se isto não fora elle não valeria nada em França, nem em Portugal [...]». E perguntava, logicamente, «[...] como será razam que os Francezes o vão colher defendendo-o eu a meus vassalos, e que me tomem o meu e eu perca todo este proveito [...]». (cf. Instruções para D. Francisco de Noronha, embaixador nomeado para França, Novembro de 1540, B.N.L., cód. 886, fól. 486).

Comentemos: os múltiplos usos de um recurso natural quando interessam a actores diferentes já são susceptíveis de gerarem situações de conflito; tratando-se de um com um só uso, é óbvio que a cascata de conflitos entre actores concorrenciais irrompe com mais facilidade e com mais intensidade. Assim, sob esta última perspectiva e no caso concreto do Brasil, D. João III teve que pagar caro, mesmo financeiramente, o defeso do comércio do pau tintorial. 
Com particular incidência nos anos 30 e 40 da era de Quinhentos, a pirataria francesa obrigará D. João III a organizar armadas para, em particular, defender o Brasil e a Costa da Malagueta. Apenas dois exemplos: em 1532, chegará a dar poderes a Duarte Coelho para erguer fortalezas na Costa da Malagueta e, no ano seguinte, Martim Afonso de Sousa correrá a costa do Brasil, acabando por, além do mais, tomar aos franceses uma fortaleza por eles erguida em Pernambuco.

Assim, em 1542, o vedor da Fazenda de D. João III, o Conde da Castanheira, resumirá deste modo os resultados da política joanina referente aos dois espaços ultramarinos em causa: «O trato da Malagueta he devasso de vinte e oito e [ou] vinte e nove annos a esta parte e porque as dividas e occupações de Vossa Alteza forão crecendo, se não tratou mais disso». Por sua vez, «no Brasil tem Vossa Alteza gastado muyto dinheiro, e começou a gastar no anno de 1530. Misteryo foy grande fazer-se a primeira despesa a fim de cousa que o não merecia [sublinhe-se], e seguir-se delia descarregarem-se daquella terra os francezes, que já nella se começavão a prantar e lançar raizes» (De uma carta do Conde, in Annaes de Elrei Dom João Terceiro, por Fr. Luiz de Sousa, publicados por A. Herculano, Lisboa, Typ. da Sociedade Propagadora dos Conhecimentos Uteis, 1844, pp. 456-459).

Esclareça-se que, de um registo de Despezas extraordinárias, que se fizerão nos negocios abaixo declarados, que succederão despois que Elrey D. João o $3^{\circ}$ e nosso senhor reinou (B.N.L., cód. 886, fóls 715 e segs.), mas só até ao ano de 1544, constam as seguintes notas: «O Brazil nam somente nam rende ao anno athegora, o que sohia a render, mas tem custado a defendelo - mais de 60000 cruzados»; «A Malagueta nam tem rendido do dito a esta parte a $5^{\wedge}$ parte do que ao tempo atraz rendia, e tem custado a defender - 800000 cruzados».

Para se ter uma ordem relativa da grandeza destes números, além de poderem ser directamente cotejados, retenha-se que só com a terceira $e$ 
última armada comandada por Vasco da Gama, em 1524, «[...] se despenderião nella 200000 cruzados alem do que se podera gastar com a Armada ordinaria». Só que o Brasil não gerava, então, em termos reais, qualquer cifra que se pudesse comparar com a riqueza proveniente do «Estado da Índia», e nem sequer com a da Costa da Malagueta (em 1537, por exemplo, o quintal da malagueta ainda é vendido a 12 cruzados). Mas, potencialmente, o Brasil continuava a valer muito para D. João III, ainda que Duarte Coelho, por carta de 22 de Março de 1548, lhe pudesse, aparentemente, reparar: «Nam tenha V. A. em tam pouco estas terras do Brasill em especiall esta Nova Lusytanea [capitania de Pernambuco], como mostra ter em pouco pois nam provê nem me responde ás cartas e avysos que á tres anos e que per tres ou quatro vyas lhe tenho esprito mostra que tem, pois a yso nam aqude [...]» (in Historia da Colonização Portuguesa do Brasil, vol. III, p. 316).

Não respondia D. João III a Duarte Coelho, mas não deixava, mesmo quando então o pau pouco valia, de proclamar nas instâncias internacionais que os limites do seu Império integravam o Brasil e que o direito de conquista (próprio dos monarcas medievais) se estendia, agora, ao direito das terras e mares descobertos. Concretizando: por volta de 1535, depois de ouvido o parecer dos seus cosmógrafos, defenderá com determinação que corsários e piratas «[...] nam irám a Costa de Guiné, que começa do Cabo de Bojador por diante, nem a Costa do Brazil, começando do Rio do Parcél em diante, o qual Rio jáz do Maranhão para a banda do Norte 260 legoas nem aos mares da navegaçam da índia das ditas partes para o Sul, nem Oriente, nem por nenhuma outra parte poderam entrar de 300 legoas alem de Maluco para dentro contra as partes da índia para os Mares, e navegaçam destas partes acima dittas para dentro, que fórão descobertas pelos Portuguezes por mandado de Elrey de Portugal» (B.N.L., cód. 886, fóls, 375-376). 
Por sua vez, em 1540, D. João III instruirá deste modo D. Francisco de Noronha, embaixador nomeado para a Corte de França: «[...] porque se vos dissessem que os mares são comuns e que elles [os franceses] podem ir a descobrir por elles, e a comercear no descoberto, e querem por em justiça se podem fazer isto, parecerá couza igual sendo tam fora de rezam como seria dizer-lhe eu que me pertencia Paris ou elle[s] a mi Lisboa e dizer cada hum de nos que o pozessemos em justiça, porque as couzas que se possuem e adquirem pelos Reys não se poem em justiça com os outros Reis, quando se nam diz «isto foi meu»; e ainda então da posse se tracta primeiro, e seram mares comuns a todos; mas os outros, que nunca forão sabidos, que com tão grossas despezas e mortes de gentes se abrio caminho para elles, se não entenderam como os outros, nem ha razam nem justiça que por aquelle caminho va fazer quem quizer seu proveito, e tão razoado he isto que de cento e tantos annos que há que a costa de Malaca [Malagueta]he descuberta e tantos o Brazil, nunca nenhüa nação de homens a nenhüa destas terras foi, senão corsários Francêzes que assi como roubarião o [rei] de França se pudessem, começarão de tentar este proveito de hirem lá [...]». (B.N.L., cód. 886, fóls. 479-480).

Insistamos: é verdade que crescia a dívida pública de Portugal sobretudo com a defesa de um Império Ultramarino cada vez mais ameaçado e invejado por inimigos e amigos e extremamente repartido do ponto de vista geográfico; é verdade que era desse Império que provinha a maior fatia das receitas da Nação e, por tal, era necessário não prescindir de qualquer parcela que proporcionasse recursos. D. João III teve, porém que sacrificar, na ara do interesse público, algumas das parcelas desse Império Ultramarino (caso de certas praças do Norte de África), mas não sacrificou o Brasil, antes o defendeu contra a cobiça de estranhos, apesar de produzir apenas «cousa que o não merecia», como lembrará o seu devotado e longevo vedor da Fazenda (entre 1530 e 1557), o Conde da Castanheira. 
5. As conjunturas correspondentes aos reinados de D. João III e do seu neto continuarão, como se sabe, a ser dominadas, economicamente pelas especiarias. Vitorino Magalhães Godinho, a propósito, frisará bem que ao longo do século XVI se verificará uma subida dos preços das especiarias (menor o da pimenta) e que tal subida teve a ver com a recuperação das rotas do Levante, com o crescimento da procura chinesa e com a maior abundância dos «reales» de prata (Mito e mercadoria, Utopia e prática de navegar, p. 330). Segundo o mesmo historiador, à volta de 1515, o comércio das especiarias representava, para Portugal, cerca de um milhão de cruzados, ou seja, o equivalente às rendas eclesiásticas, menos da quarta parte do valor global do consumo de cereais, carne, vinho e azeite, o dobro do trato do ouro e dos metais. Sob outra perspectiva, o lucro líquido sobre o trato das especiarias e drogas equivalia, para o Estado, pelo menos a $40 \%$ das suas receitas (Ibidem, p. 331). Avancemos.

Em Maio de 1532, D. João III está a instruir D. Martinho que, em breve, irá por embaixador junto do Papa Clemente. Entre outras informações de que o embaixador português deveria fazer uso, constam estas: o rei de Portugal tem continuamente guerra no Norte de Africa, mas está sobretudo a fazer um esforço militar considerável na «índia». Ainda na última armada, reforçara-a com gente de guerra sobresselente e só não foi mais, porque não havia lugares nas embarcações. Haveria, então, na «Índia» mais de 10000 homens de guerra, enquadrados por gente fidalga, «com que se fáz muy grande despeza continua afora os galardoens de seus serviços» (B.N.L., cód. 886, fól. 249).

Porquê este esforço de guerra no «Estado da Índia»? Em finais de 1532, os turcos otomanos haviam logrado construir em Baçaim, uma das melhores cidades do Guzurate ou do reino de Cambaia, uma fortaleza, denunciando estarem interessados em instalar-se nessa zona, uma das mais ricas da Ásia das monções e verdadeiro motor das economias 
mercantilizadas e monetarizadas do eixo Índico-Pacífico. Refere-o, por exemplo, o português Tomé Pires, na sua Suma Oriental, ao declarar que aquele Reino era muito abastado de cereias, legumes, frutas, cavalos e elefantes, além de ser muito habitado e urbanizado (entre as suas cidades principais contavam-se as de Cambaia, Diu, Champanel, Baroche, Surrate, Damão e Baçaim). Por sua vez, Duarte Barbosa surpreender-se-á com a qualidade do artesanato do Guzurate e com os altos conhecimentos náuticos e mercantis da sua gente (cf. João Marinho dos Santos, Os Portugueses em Viagem pelo Mundo. Representações quinhentistas de cidades e vilas, Lisboa, Grupo de Trabalho do Ministério da Educação para as Comemorações dos Descobrimentos Portugueses, 1996).

Naturalmente, os portugueses estarão atentos às movimentações dos turcos e estarão, sobretudo, dispostos a contrariar as suas pretensões de domínio na zona. Assim, em carta de 20 de Julho de 1535, dirigida ao Papa Paulo III, D. João III haverá de confessar ter sido objecto particular da sua política a conquista de Diu, a porteira do golfo de Cambaia. Tal esclarecimento visava enquadrar certos êxitos, como o facto de, em 1534, o governador do Estado da Índia, Nuno da Cunha, a troco de auxílio militar, ter conseguido que os guzurates lhe entregassem a fortaleza e a cidade de Baçaim e, no ano seguinte, ter alcançado permissão para erguer em Diu uma fortaleza.

E D. João III explicitava, deste modo, a sua estratégia regional: pretendia erguer em Diu um baluarte que fosse o padrasto principal do seu poder na Ásia; retirar aos turcos essa importante base de asilo; assenhorear-se mais, com a posse daquela importante cidade portuária, do comércio oriental.

Em 1538, assiste-se ao designado «primeiro cerco de Diu» e, em Abril desse ano, D. João III recomenda ao seu embaixador em Roma que, perante os grandes armamentos do turco no Índico, motive o Papa 
para acudir, financeira e espiritualmente, ao reino de Portugal na guerra que fazia na Índia contra tão poderosos inimigos da Cristandade. Só que ao Sumo Pontífice preocupava-o muito mais o facto de ter o mesmo inimigo ao pé da porta. Lembremos que, em 1540, os venezianos assinaram um tratado de paz com os turcos em que se desenhava a possibilidade de, por intermédio de Veneza e do Papa, os otomanos estabelecerem também tréguas com os castelhanos e os franceses, deixando Portugal de fora e a braços com sérias dificuldades militares na Índia e no Norte de África (B.N.L., cód. 886).

É, pois nesta conjuntura, que se deve entender a decisão político-estratégica de D. João III de sacrificar algumas praças portuguesas no Norte de África, principiando por abandonar Santa Cruz do Cabo de Guer, ainda em 1540.

Em 1546, os turcos estão decididos a tomarem Bassorá e a atacarem fortemente os portugueses na Índia através das rotas que conduziam ao Golfo Pérsico, sem contudo, prescindirem, igualmente, do domínio do Mar Roxo. É o que se poderá depreender, designadamente, de uma carta do governador de Bagdade para o rei de Gizara, preferindo este apoiar-se, política e militarmente, nos portugueses (através da nossa fortaleza de Ormuz) em vez de recorrer aos turcos. Igual decisão era perfilhada pelo rei de Bassorá. Contudo, ainda em 1546, será o terrível cerco de Diu e, na Etiópia, prosseguirá o auxílio português ao Preste contra o rei «mouro» de Zeila, apoiado, pelos turcos (cf., João Marinhos dos Santos, A Guerra e as guerras na Expansão Portuguesa, séculos XV e XVI, Lisboa, Grupo de Trabalho do Ministério da Educação para as Comemorações dos Descobrimentos Portugueses, 1998). Em resumo: a investida turca, tanto pelo Mar Roxo, como pelo Golfo Pérsico, é fortemente sustida pelos portugueses, mas à custa de muito sangue e de muito dinheiro. Este era conseguido, a elevados juros, nas praças de Flandres e o principal aval continuava a ser a pimenta da Índia. 
Tanto assim era que, de alguns alvitres registados em Goa, em 1545, colhe-se, facilmente, a opinião dominante de que o monopólio régio desta especiaria deveria ser defendido a todo o custo: «E a pimenta parece que se havia de ter por sagrada para que com ela se nom bolisse maes que pera o Reino» - opinará um arbitrista (cf. doc. 11 de A Questão da Pimenta em meados do século XVI, por Luís Filipe F. R. Thomaz, Lisboa, Universidade Católica Portuguesa, 1998).

Só que a pimenta da Indochina e da Insulíndia passou a concorrer com a pimenta do Malavar, para além de não conseguirmos estancar a hemorragia do trato que escapava ao nosso controlo, tanto pelo Mar Roxo, como pelas vias do Golfo Pérsico que desembocavam no Levante. Assim, segundo Vitorino Magalhães Godinho, de 1554 a 1565, afluirão, anualmente e pela via do Mar Roxo, ao Mediterrâneo entre 20000 a 40000 quintais de pimenta. Quanto às vias do Levante, elas reanimar-se-ão, apesar de haver, entre nós, quem preconizasse que se reforçasse militarmente Ormuz (uma decisão realista) ou até mesmo que se tomasse aos turcos a fortaleza de Bassorá (praticamente impossível). Vingou a via da política externa e da diplomacia, ou seja, o entendimento secreto com o turco, de que é exemplo uma tentativa (fracassada) logo em 1541 (Annaes de D. João Terceiro, pp. 358-359).

De qualquer modo, a pimenta manter-se-á, durante várias décadas (praticamente até finais da era de Quinhentos) como a mercadoria mais valiosa do Império colonial português. Em 1561, por exemplo, D. Álvaro de Castro, alheio por certo aos graves problemas financeiros da Fazenda real, ainda reivindicará mais gente militar para a Índia, porque sem pimenta, dizia, não se «podera soster Portugal» (Documentação anexa a Alguns aspectos da ameaça turca sobre a índia por meados do século XVI, por Luís de Albuquerque, Lisboa, Junta de Investigações do Ultramar, 1977). Só que a concorrência estrangeira era muita e Portugal estava, sobretudo financeiramente, exausto. 
6. Quando é que soou a hora do açúcar brasileiro? Entendamo-nos: todo o espaço é, antes do mais, um meio de vida susceptível de viabilizar diversas actividades humanas e o Brasil, à medida que foi sendo geoeconomicamente convertido em recurso, transformou-se em território, em pátria, para muitos alógenos. Dito de outro modo: ao alargarem o novo espaço, os primeiros europeus tiveram necessidade de o povoar, de o organizar, de estabelecer com ele uma relação afectiva, de o defender perante atitudes agressivas, de o conservar (designadamente, através da sua descedência). Este processo contou, necessariamente, com o papel estruturante de instituições básicas ou tradicionais, mas teve a suportá-lo, também e muito, a iniciativa individual, pelo que, a par da via oficial que tende a integrar o Brasil na colonização portuguesa, se terá que prestar também atenção ao esforço dos particulares. Só, com esta perspectiva, aplicável a outras situações, se compreenderá como, de um momento para o outro, irrompem borbotões de vida que, oficialmente, não era suposto existirem. Tal surpresa poderá tê-lo sido tanto para os decisores do Poder, em qualquer época, como para os que a estudam, em particular os historiadores, sobretudo, se aplicarem modelos interpretativos resvaladiços, como o dos ciclos económicos.

Procurando perscrutar os primeiros passos da iniciativa privada no âmbito da colonização brasileira, como era de esperar os registos escritos são raros e difusos. Jaime Cortesão faz datar de 1516 a institucionalização da capitania do mar do Brasil e opina que terá sido por essa altura que arrancou o povoamento europeu e o trabalho de plantação das primeiras canas de açúcar. Supõe-se que, entre 1520 e 1526, terá saído, por Pernambuco, algum açúcar. Pouca coisa, porém, já que é ponto assente que só com Martim Afonso de Sousa (1533-1534) é que se introduz a cana de açúcar em dimensões visíveis. Em S. Vicente montou-se o primeiro engenho, designado Engenho do capitão-mor e, depois, dos 
Armadores e, ainda de S. Jorge dos Erasmos, por ter sido também seu proprietário um Erasmo Schetz, flamengo e comerciante de pimenta na «Casa da Índia» de Lisboa.

$\mathrm{O}$ arranque da industrialização açucareira do Brasil deveremos fixá-lo, segundo Vitorino Magalhães Godinho, na década de 1540. Em 1548, haverá em S. Vicente 6 engenhos, mais de 600 povoadores brancos e cerca de 3000 escravos.

Não vamos analisar a evolução da economia açucareira, nem muito menos esboçar uma síntese. Importa-nos, somente, assinalar o momento em que a referida economia passou a pesar na balança comercial do reino de Portugal, o que, obviamente, exige uma perspectiva de relatividade. Citando Magalhães Godinho: «A meio de Quinhentos situa-se, por conseguinte, a grande viragem em relação ao Brasil, da economia de escambo para a economia de produção, dominada pela procura de mão-de-obra que, além de avolumar sensacionalmente o tráfico negreiro, é uma das determinantes das bandeiras, por esses tempos» (Os Descobrimentos e a Economia Mundial, vol. 2, Lisboa, Editora Arcádia, 1965, p. 461).

Geograficamente, é sabido que, a partir de meados de Quinhentos, o centro e o sul do Brasil vão perdendo importância quanto à cana, em benefício do Nordeste. Mas, na década de 1570, como se disse, ainda o Império colonial português gravita ao redor da pimenta e da prata necessária para a adquirir nos mercados da Ásia das Monções.

É sabido como as mercantilizadas e monetarizadas economias do eixo do Índico-Pacífico exigiam moedas, pré e para-moedas adequadas à aquisição das várias mercadorias. Independentemente das variações conjunturais locais e até da variação anual dos preços, rapidamente os portugueses concluíram que era o pagamento de contado em ouro, prata e cobre que possibilitava os melhores preços de aquisição das especiarias, em particular da pimenta. De tal modo, esta forma de pagamento se 
arreigou e não apenas nos centros decisores, que, em uns Apontamentos que os prelados do Reino fizeram para serem considerados nas cortes de Lisboa, de 1562 (convocadas, fundamentalmente, para se encontrarem soluções para a grave crise financeira nacional), se pede: que os vice-reis e governadores da Índia mandem mais pimenta, «e que para o emprego da dita especiaria se lhe[s] mande ouro e prata fina como se pede pelos que nisso entendem, porque esta hé cauza por que se vende antes aos Turcos que a nós, e assim se mande todo o cobre que se pede tão importante ao serviço de S. A. e bem daquelle Estado» (B.N.L. cód. 8102).

Faltavam, porém, agora mais do que nunca, em Portugal os famosos «reales» que viabilizavam grande parte do comércio ultramarino. Razões? Várias, mas, sobretudo, a maior valorização da prata nos Países do Noroeste Europeu do que na Península Ibérica e, por isso, o metal e as moedas argentíferas escoavam-se para ali. Deste modo, Portugal, buscará então, quase desesperadamente, minas de metais amoedáveis dentro das fronteiras do seu Império (a colonização de Angola, encetada em 1575 e centrada na utopia das serras de prata de Cambambe é disso exemplo), além de continuar a atrair a prata espanhola através de uma política financeira que lhe desse vantagem relativa em Lisboa.

Entretanto, o crescimento da produção açucareira do Brasil empola-se no começo da união das duas Coroas peninsulares. Em 1590, estima-se que o dízimo dos açúcares do Brasil poderia atingir a cifra de 50250 arrobas, ou seja, a produção global ultrapassaria já as 500000 arrobas. Com a arroba a valer 800rs, conclui-se, facilmente, que o valor do açúcar brasileiro se cifrava, então, no milhão de cruzados, ou seja, tanto quanto terá valido, à volta de 1515, para Portugal, o comércio das especiarias orientais. 